\title{
Research on the Political Faith Education of Students in Higher Vocational Colleges Under the Background of Full and Strict Governance Over the Party
}

\author{
Qian Li*, Huan Xiong \\ Department of Resources and Environment, Yunnan Land and Resources Vocational College, Kunming, 650002 \\ *Corresponding author. Email: 252098073@qq.com
}

\begin{abstract}
The methodological research on the political faith education of students in vocational colleges is an important subject to enrich the research of the way of ideological and political education of college students. Political faith education of students in higher vocational colleges under the background of full and strict governance over the Party is of great and far-reaching significance for improving the overall quality of students in vocational colleges, cultivating qualified builders and reliable successors to the cause of socialism with Chinese characteristics, realizing the goal of "two 100 years" and realizing the Chinese dream. This paper intends to study and discuss the political faith education work of students in vocational colleges from the following two aspects of the significance of political faith education of students in higher vocational colleges and the path of political faith education of students in higher vocational colleges under the background of full and strict governance over the Party.
\end{abstract}

Keywords: Strict governance over the Party, Higher vocational colleges, Political faith education.

\section{INTRODUCTION}

Since the 18th CPC National Congress, the CPC Central Committee has implemented a major strategic plan for exercising full and strict governance over the Party. On October 8, 2014, General Secretary Xi Jinping put forward for the first time the plan of "exercising full and strict governance over the Party" in his speech at the summary meeting of activities to see members command and act on the Party's mass line, pointing out that full and strict governance over the Party takes "full" as base, "strict" as key factor and "governance" as the strategic point.

In the 19th CPC National Congress, the new requirements for full and strict governance over the Party were put forward, according to which, we should unswervingly and strictly implement the plan of full and strict governance over the Party, adhere to the two " unswervingly" and adhere to the leadership under Marxist ruling party. In recent years, with the rapid growth in number of students in higher vocational colleges, it is the obligatory duty and responsibility of higher vocational colleges to train high-skilled talents with excellent political quality and professional skills for the country.

\section{SIGNIFICANCE OF POLITICAL FAITH EDUCATION OF STUDENTS IN HIGHER VOCATIONAL COLLEGES}

\subsection{The political faith education of students in higher vocational colleges is necessary for students' sound development in mind and body.}

The students enrolled in higher vocational college students are from complex sources, such as junior high school, senior high school and technical secondary school. They are in an important period of shaping their outlook on world, life and values. Although most of the students have reached the age of majority, imitation psychology, group psychology and even rebellious attitude are still their main characteristics in the stage of physical and mental development. Therefore, it is deemed as an important link to offer political faith education for students in higher vocational colleges as soon as possible, so as to help them establish beliefs in the pursuit of ideals, enhance their sense of responsibility and mission of the times, and this is also an important measure to promote them to form correct "three values", realize their ambitions as early as possible and make contributions to the country. 


\subsection{The political faith of students in higher vocational colleges is required for "two-highs" construction of higher vocational colleges.}

On January 24, 2019, the State Council issued the Implementation Plan for National Vocational Education Reform, indicating the launch and implementation of high-level higher vocational schools and professional education program with Chinese characteristics (referred to as the "two-highs" program). Many higher vocational colleges take it as their ultimate goal of college development to improve the standard and quality for running schools. As we know that the students are the carriers of improving the standard and quality for running a school, the political faith education of students in higher vocational colleges is the most basic foundation for the application of "two-highs" construction program in higher vocational colleges, and colleges whose students have firm political faith, outstanding craftsman spirit and excellent professional ethics must have excellent faculties, good practice and training conditions and reasonable talent training system.

\subsection{The political faith education of students in higher vocational colleges is necessary for national economic development.}

As clearly pointed out in the report of the 19th CPC National Congress, "China's economy has been transitioning from a phase of rapid growth to a stage of high-quality development. This is a pivotal stage for transforming our growth model, improving our economic structure, and fostering new drivers of growth". Students in higher vocational colleges are the fresh troops of national economic construction in the new era due to their high level of knowledge, professional skills, high comprehensive quality and strong practical ability, and they are well educated in political faith since they enter the school, are determined to become the great country craftsman and exert their own strength for national construction with their professional skills. Only by firmly establishing political faith in their minds can they become the reliable builders and successors of socialistic China.

\subsection{The political faith education of students in higher vocational colleges is necessary for the strategic development of the "Belt and Road".}

The Belt and Road Initiative, short for the Silk Road Economic Belt and the 21st Century Maritime Silk Road, is an economic cooperation initiative proposed by Chinese President Xi Jinping in September and October 2013 respectively. As of November 2020, China has signed 101 cooperation documents with 138 countries and 31 international organizations for jointly building the "Belt and Road", and for this purpose, more and more high-skilled talents with knowledge and high level of education from all walks of life to go out and work actively to promote the development of the world economy. Meanwhile, after students in higher vocational colleges who have firm political faith and solid professional skills go abroad, their national selfconfidence and pride are boosted, and will win worldwide acclaim as a great country craftsman.

\section{PATH OF POLITICAL FAITH EDUCATION OF STUDENTS IN HIGHER VOCATIONAL COLLEGES UNDER BACKGROUND OF FULL AND STRICT GOVERNANCE OVER THE PARTY.}

On January 10, 2021, as pointed out in the National Education Work Conference that "vocational education work shall focus on quality", and the "quality" refers to good quality. To build good quality, the talent is the key factor. Therefore, in the process of political faith education of students in higher vocational colleges under background of full and strict governance over the Party, it should adhere to right leadership, perfect various rules and regulations, stimulate students' internal motivation and promote the construction of fronts at all levels, aiming to guide students in higher vocational colleges to establish firm political faith and become "professionals" shouldering the historic mission of national rejuvenation.

\subsection{Give full play to the role of primary-level Party organization}

Higher vocational colleges must be under the leadership of the Party. Adhering to the leadership of the Party is the fundamental prerequisite for higher education development. By delivering the speeches at the National Conference on Publicity and Ideological Work in 2013 and at the Sixth Plenary Session of the 18th Central Commission for Discipline Inspection in 2016, General Secretary Xi Jinping stressed "the Party Committee bears the main responsibility for ideological work" and "the Party Committee bears the main responsibility for full and strict governance over the Party", which has sent a clear message that the important components of the main body of political faith education in colleges and universities for higher education are Party committees and Party organizations at all levels, which requires Party committees and Party organizations at all levels in in colleges and universities to shoulder the main responsibility of political faith education of students in colleges and universities and adhere to the principle of integrating strict governance and scientific governance. 


\subsubsection{Party committees of higher vocational colleges shall lead the direction of political work and take charge of top-level design of political faith education.}

Party committees in higher vocational colleges shall lead the direction of political faith education, and firmly seize the leadership, right of speech and administrative authority in terms of the new content and expression of ideology and construction of new media, "change as time and circumstances change", adhere to socialist orientation in running schools, earnestly implement the guidance work of ideological and political education for college students, make efforts in top-level design of political faith education of students in higher vocational colleges, take effective means of full and strict governance over the Party to set exact demands on teachers and students who are Party members, implement the list of duties at all levels, improve the quality of plan of full and strict governance over the Party, launch the "Young Marxists Training Program", finally forms the working pattern under the unified leadership by the Party Committee of higher vocational colleges and joint efforts by departments and organizations at all levels, strengthen collaborative education and make joint efforts in education.

\subsubsection{Primary-level Party organization shall strictly implement the Work Regulations of the CPC Primary-level Organizations in General Institutes of Higher Education, and organize faith education activities with the respective characteristics.}

On the basis of strictly implementing the Work Regulations of the CPC Primary-level Organizations in General Institutes of Higher Education, in the process of political faith education in colleges and universities for higher education, it is required to carry out solid political studies, highlight the project research, business guidance, responsibility implementation, etc. by means of integrating discussion and case-based teaching, seek for continuous progress with time combined with Internet big data platform, integrate the political faith education into the teaching content of ideological and political courses, innovate the education mode of ideological and political courses considering the fragmented, socialized and interest-based reading features of students in higher vocational colleges to actively make political faith education more close to the masses and life, fully reflect the characteristics of the times, comprehensively adopt the new media technology to improve teaching quality and teaching effect in a manner of integrating pictures and texts, sound and images, and pay attention to multi-party coordination to reconstruct the expression mechanism of mainstream ideology. Relying on the strength of Youth
League general branch, it shall actively promote excellent cases about daily organization activity to the primary-level Youth League branches, and further carry out diversified and unique activities such as theoretical study, emotional education and "education on Party history, National history, reform and opening up history and socialist development history" of primary-level Party organizations.

\subsubsection{Party branches at all levels shall strictly control the application for joining the Party and play the role of fortress for political faith education.}

Party branches at all levels shall strictly strengthen the political faith education of students in higher vocational colleges according to 5 stages and 25 steps required for Party members' development so as to improve the ideological quality and theoretical level of students in higher vocational college in an all-round way, as well as shall launch a series of activities such as education and training on the motivation of joining the Party, recommendation of excellent League members, training of activists and members to be admitted, etc. and participate in activities such as Party history and conditions education and "Re-visiting the Long March Road" together with teachers who are Party members, aiming to make students have a better and deeper understanding of Party history and conditions and the future and destiny of the country and aware of their social responsibilities, to improve their skills and talents, enhance their national self-esteem, pride and self-confidence, thus further achieving the purpose of education, encouragement and inspiration, help them reshape their values and beliefs, and cultivate their excellent qualities of perseverance and hard work.

\subsection{Establish and improve the system of political faith education of students in higher vocational colleges}

\subsubsection{Improve the operating system of political faith education}

Under the strong leadership of the Party Committee of the colleges, it shall strengthen the institutional improvement in the process of political faith education. Firstly, it needs to improve the implementation and coordination system of administrative departments at all levels. Secondly, political faith education includes classroom teaching and various educational activities, and it is necessary to establish corresponding system to ensure the effectiveness of these educational methods. In terms of classroom teaching, it is required to set institutional requirements on the number of teachers and the class hours as well as build a regular learning and training system for course teachers, so as to 
continuously improve teachers' theoretical attainment and to enhance teachers' enthusiasm for creative teaching by holding more appraisal and competition activities. In addition, it shall establish statistical system indicating how many times educational practice activities (such as visiting patriotic education bases, visiting revolutionary pioneers, attending various forms of training lectures, etc.) are held as well as the number of participants, and upon participation in such activities, various communication activities shall be strengthened to form deep impression. The practical activities shall be implemented in a standardized manner through institutionalization means, so as to ensure the smoothness of practical activities. Its stable implementation can gradually improve the effectiveness of practical education activities, to achieve the purpose that once the activity is held, it will achieve initial success.

\subsubsection{Improve the evaluation system for political faith education}

Firstly, it is necessary to set up and improve a specialized evaluation department to gradually realize standardization, institutionalization, and normalization of the information collection and evaluation in a timely and accurate manner, and in this way, which enables the collection and processing of information reflecting students' ideological state in various aspects and through various channels, thus providing a basis for making new decisions; Secondly, it shall improve scientific evaluation index and evaluation procedures. In the evaluation system, the operable and measurable evaluation indexes shall be used as the physical form to reflect the ideological trends of college students in the process of education. Different index systems shall be established according to the contents and forms of classroom teaching and practical activities, as well as be subject to real-time upgrading as the time changes. In the new era, the ideological trends of students in higher vocational colleges new characteristics, so various index systems used for evaluation shall be ready for adjustment accordingly. Meanwhile, it shall adopt scientific procedures in the evaluation process, formulate a unified standard and index system on the premise of determining the evaluation objectives, collect and analyze effective information, carry out quantitative and qualitative evaluation, on the basis of which, give feedback and make summary, go through the next round of evaluation, and ensure the scientific and fair evaluation, so as to truly play the role of education evaluation.

\subsection{Stimulate the internal motivation of political faith education of students in higher vocational colleges}

\subsubsection{Improve the construction of internal faith of students in higher vocational colleges}

Firstly, improve internal faith and self-cognition. Strengthen the awareness of self-learning and comprehension, deeply take use of the convenience brought by multimedia technology improvement, enhance the ability of active learning and making a clear distinction between right and wrong, and form good habits. Students shall adopt self-questioning strategies to promote the knowledge processing in the brain. It is required to ask questions about their faith, knowledge and confusion and find a solution, so as to realize observation, evaluation and management of self-faith in this process. Through self-examination and adjustment, students can form a firm belief, understand their ideological trends and faith cognition conditions timely and accurately, and ensure the effectiveness for generation of political faith.

Secondly, hone your will to believe. College students need to understand their faith demands, actively link political faith with actual life and growing environment, and learn to make choices under the guidance of political faith. College students, no matter whether they have established faith or are on the way of seeking for the faith, shall actively learn and use Marxist world outlook and methodology as guidance principle; College students shall constantly hone their will to believe and transform from "passionate" stage to stable and firm stage. This higher vocational college requires that college students shall think rationally when they are confused or encounter unfair and unreasonable social phenomenon and resist bad ideological thoughts.

\subsubsection{Promote the awakening of self-faith consciousness of students in higher vocational colleges}

On one hand, organize more theoretical practice activities. Firstly, arouse the enthusiasm of college students to participate in the classroom activities about political faith education, especially the discussion meeting about Marx and communism stories, and the discussion meeting on how political faith guides life. Meanwhile, actively participate in the practical activities organized by the Party branches, Communist Youth League and clubs, participate in the Party history contests, learning groups etc., have a deep understanding and recognition of the Party, and get insight into the important effect of choosing Marxism on the Chinese nation. Secondly, encourage college students to consciously carry out living and practice activities under guidance of political faith, actively 
fulfill the principle of political faith in daily life, and apply mastered theory into practical activities that help them understand and transform the world, so as to have a deeper understanding of political faith, realize scientific nature and value of Marxism, and transform rational faith into emotional identity.

On the other hand, experience a different life. Encourage college students to actively participate in volunteer service activities such as going to the countryside and voluntary teaching, and to visit representative sacred place for the revolution during winter and summer vacations. College students who participate in volunteer service activities can better serve the people using their knowledge, enhance their sense of gain and sense of accomplishment, and become more confident and determined in Marxism; By visiting the sacred place for the revolution, comprehend intensely the correctness and historical inevitability of the Chinese nation to choose Marxism, and feel the inherent charm, affinity and cohesion of Marxism.

\subsubsection{Guide college students to carry out self- positioning of faith}

Firstly, set a clear demand. The teachers in higher vocational colleges who are Party members shall guide college students to go out of dormitories and classrooms, communicate with excellent peers, exert peer effect, influence more college students, find their places through communication with others and set higher goals and develop ambitions according to their actual situation. Divide long-term goals into several short-term goals, have a dream, try to achieve it by working hard.

Secondly, set a faith goal. Students in higher vocational colleges shall take the initiative to combine their goals with socialist modernization construction, keep pace with national development, and actively come closer to the Party organization. Only by setting correct big target can you avoid deviation of your small targets. Since the outbreak of COVID-19 pandemic, tens of thousands of younger generations joined the medical team aiding Hubei. The protective goggles and medical masks are worn by young faces, and the loose protective clothing covers firm belief. Guide college students to "correctly understand their great ambitions, cherish their glorious youth time, be practical and transform great ambitions into practical actions" [1]. In the places where the Party and the people are in great need, they are growing in full bloom. Take these young people as examples and firmly establish political faith.

\subsection{Consolidate construction achievement in the field of political faith education of students in higher vocational colleges}

\subsubsection{Promote the construction of schools as main battle field}

Firstly, further strengthen the vivid teaching in theoretical education. On the basis of the previous classroom education on theoretical knowledge, higher vocational colleges shall further promote the vivid teaching on Marxist theory, and teach scientific theory by using classic means and in combination with characteristics of the time, so as to keep close to the actual life and thoughts of college students, and continuously inject fresh blood, so as to achieve the goal of profound theoretical education.

Secondly, strengthen the construction of campus culture Further strengthen the construction of campus culture and create a positive cultural atmosphere, thus driving formation of college students' political faith. Firstly, give full play to the "leader effect" of student Party members. Give full play to the leading role of student Party members at primary-level organizations, strengthen progressive education among student Party members, follow high standards and strict requirements of Party organizations to show the charm of Party culture, drive peer students to take the initiative in learning, and enhance their ideological cohesion and political centripetal force; Secondly, continue to launch cultural activities on building excellent campus Build positive campus culture to provide a platform for students with diverse interests to express themselves as well as a channel to broaden their knowledge, and meanwhile, adopt vivid and dramatic means to share positive contents, and promote the college students to form correct values. In addition, actively organize learning activities in educational bases, and organize college students to visit designated places, such as patriotic education bases, sacred place for the revolution like Yan'an, Jinggangshan, etc., to make college students impressively and truly experience the charm of political faith, generate emotional resonance and enhance trust in political emotional tendencies. In addition to learning activities at the education base, organize college students to visit revolutionary pioneers in local places and watch revolutionary documentaries, help college students better understand the glorious history of unremitting struggle of the Party and the people united under the Party and deeply understand the historical responsibility of youth in contemporary era. 


\subsubsection{Promote the construction of well- coordinated and inter-connected relationship between government and families}

Firstly, in the process of political faith education, the government shall highlight the top-level design. The main purpose of political faith education is to strengthen the recognition of members of society towards the Party and government, thus laying a legal foundation for its governance. The government shall set goals, formulate policies, constantly launch advanced education methods and systems, and adjust policy in a targeted manner; Secondly, the families shall give full play to the role of minimum guarantee. The government shall establish the concept of common education, take family as one of the main bodies of education, pay attention to the continuous political faith education by parents, establish a long-term communication mechanism, pay a regular visit, and give full play to the minimum guarantee role of family in the process of political faith education. The political faith education in schools is carried out based on the top-level design of the government, aiming to achieve the same goal as that of government, and meanwhile, the family education plays the synergistic effect. After the youth is admitted to the university, it shall expand and strengthen the political cognition and emotion gained by college students through family education. Therefore, the government and the family play an indispensable role in promoting the political faith education of college students. Only by further constructing the radiation model with schools as the main part can we promote the linked education of schools, government and families and promote and strengthen the formation of college students' scientific political faith in an all-around manner.

\subsubsection{Consolidate construction achievement in the field of all-media faith}

Firstly, construct and improve the campus all-media center. The campus all-media center needs to be planned in a unified manner so as to integrate information collection, decision-making, editing, review and product release in an all-around manner. The information collection department is responsible for timely collection and upgrading of information, the decisionmaking department selects the information and specifies the information to be released, the editing department edits, produces and reviews the information in various media platforms, then submits to publication platform to launch such products in real time through various media platforms, and technical support department is responsible for technical support and timely maintenance. Therefore, all departments shall work in coordination according to respective responsibilities, ensuring that relevant information can be released at the first time to realize full coverage and form a linked publicity mechanism in campus.
Secondly, build a characteristic media brand. Brand media shall be built based on uniqueness, so that campus media can be more targeted and play a role of backbone, so as to form the cultural interaction between reality and virtual life, guide the formation of the values of the youth and stimulate their enthusiasm for political participation. Therefore, in terms of creation of various major Apps, construction of WeChat official account or the opening of related websites etc., it shall take Marxist political faith education as main goal, focus on the ideological guidance and value shaping of college students, select clear contents and classify functions in an easy but comprehensive manner, on the basis of which, it shall take more vivid and active forms to build their own styles according to the characteristics of the campus, and develop a media brand integrating ideological quality, theoretical quality and artistic quality. Meanwhile, it shall be fully close to the actual life of college students in the process of brand building. No matter in terms of early-stage research, production process or user experience feedback, timely adjustment and improvement is required by considering the actual demands of students. When the brand is launched, necessary online and offline publicity activities shall be carried out to make the brand media more attractive and realize wide application among students.

\section{CONCLUSIONS}

In brief, the political faith education of students in higher vocational colleges under background of full and strict governance over the Party needs the support of the whole society, and to achieve this goal, it shall lay an education foundation with Marxist world outlook, socialist political system with Chinese characteristics and socialist core value, following the characteristics of students in higher vocational college in the new era, and give full play to the leading role of the Party Committee of higher vocational colleges, strengthen the construction of campus culture led by political culture of the Communist Party of China, improving a series of systems required for political faith education of students in higher vocational colleges, and continuously promote the construction of various battle fields concerning political faith education of students in higher vocational colleges in the new era to improve the effectiveness of political faith education.

\section{ACKNOWLEDGMENTS}

About the author: Qian Li (1979-), female, Han ethnic group, born in Yuanjiang, Hunan Province, the Party Secretary of Department of Resources and Environment, Yunnan Land and Resources Vocational College, a major of higher education, master's degree, the associate professor, research direction: Teaching research on higher vocational education. 


\section{REFERENCES}

[1] Jinping Xi: Jinping Xi -The Governance of China, (Volume II) [M]. Foreign Languages Press, 2017: 378. 2019-3-16.

[2] Theoretical Research on the Political Faith Education of Students in Higher Vocational Colleges in the New Era [D], China University of Mining and Technology, July 2020.7.

[3] Research on Marxist Belief Education of College Students in the New Era [D], Shenyang Normal University, May 2020.5. 